\title{
Results from the Czech Republic's 2018 Report Card on Physical Activity for Children and Youth
}

\author{
Aleš Gába, Lukáš Rubín, Petr Badura, Eliška Roubalová, Erik Sigmund, Michal Kudláček, \\ Dagmar Sigmundová, Jan Dygrýn, and Zdenek Hamrik
}

\section{Introduction}

Regular physical activity (PA) is associated with numerous health benefits and plays an important role in disease prevention. However, the decreasing level of PA and increasing screen-time among Czech schoolchildren has been well documented in the last two decades. ${ }^{1,2}$ Physical inactivity together with sedentary behaviors increase all-causes mortality ${ }^{3}$ and has a high economic burden. ${ }^{4}$ To build effective intervention and prevention programs, it is necessary to review all available sources of evidence. Therefore, the aim of this paper is to summarize the results of the first Czech Report Card on Physical Activity for Children and Youth based on a synthesis of the most recently available evidence.

\section{Methods}

The Report Card included the 10 indicators that are common to the Global Matrix 3.0. To assess the indicator grades, a multilevel search strategy was used to find all relevant sources that provide published/unpublished data collected from 2013 through 2018. We retrieved 724 records from database search and 81 records by searching grey literature, hand searching and collecting recommended sources from national experts. After removing duplicates and after screening of all records, a total of 40 records were identified as eligible for data extraction. The data were synthesized from multiple sources and a set of benchmarks was used to assign grades for all indicators. The grading framework and benchmarks used are common for all countries participating in Global Matrix 3.0. The main sources were studies that were part of the Health Behaviour in School-Aged Children survey (HBSC), International Physical Activity and the Environmental Network (IPEN) study, research projects funded by the Ministry of Education, Youth and Sports and Czech Science Foundation, and surveys supported by the Czech School Inspectorate (CSI) and Czech Olympic Committee. Final grades were assigned upon consensus of all members of the national research work group (Table 1).

\section{Results and Discussion}

Overall PA in Czech children and youth was observed to be inadequate, with high rates of excessive screen-time and low numbers of children and youth spending time in unstructured/ unorganized play. On the other hand, some grades indicated promising foundations to build on in future. They are represented, for instance, by a relatively high number of children and youth participating in organized sports and/or PA programs, or generally PA-friendly setting (e.g., family, school, and built environment). Grasping these opportunities could improve current unsatisfactory state of overall PA level among Czech children and youth.

This was the first time the Czech Republic became involved in the Global Matrix project (Figure 1). The data retrieved enabled to assign grades to all 10 indicators. However, some data were missing for a few benchmarks, which could be indicative of future research directions. In addition, most of the data used for compiling the Report Card were based on self-report assessment tools.

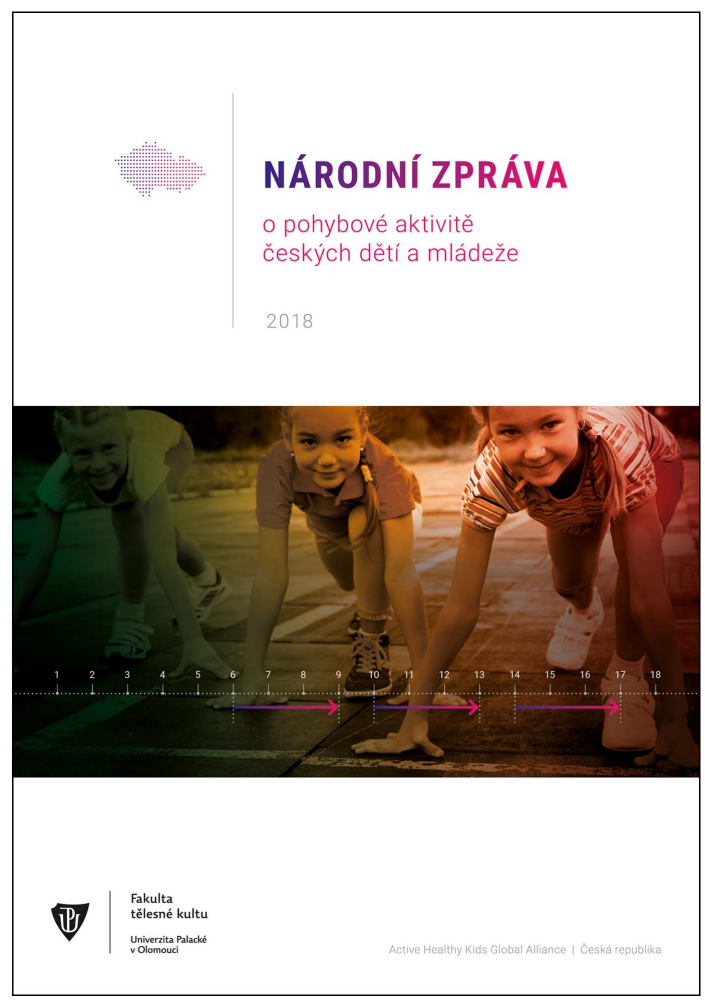

Figure 1 - Czech Republic's 2018 Report Card cover.

Gába, Rubín, Badura, Roubalová, Sigmund, Kudláček, Sigmundová, Dygrýn, and Hamrik are with the Faculty of Physical Culture, Palacký University Olomouc, Olomouc, Czech Republic. Gába (ales.gaba@upol.cz) is corresponding author. 
Table 1 Grades and rationales for the Czech Republic's 2018 Report Card

\begin{tabular}{|c|c|c|}
\hline Indicator & Grade & Rationale \\
\hline $\begin{array}{l}\text { Overall Physical } \\
\text { Activity }\end{array}$ & $\mathrm{D}$ & $\begin{array}{l}\text { Studies using objective PA assessment tools (pooled sample: } 973 \text {, only one has been published }{ }^{5} \text { ) report that } 35 \% \text { of } \\
\text { children and youth accumulate at least } 60 \text { minutes of moderate-to-vigorous PA per day. } \\
\text { According to } 2014 \text { HBSC survey, }{ }^{1} 26 \% \text { of boys and } 19 \% \text { of girls meet the PA guidelines. }\end{array}$ \\
\hline $\begin{array}{l}\text { Organized Sport } \\
\text { Participation }\end{array}$ & B- & $63 \%$ of children and youth participate in organized sport and/or PA programs (HBSC, unpublished). \\
\hline Active Play & D- & $\begin{array}{l}27 \% \text { of children and youth report unstructured/unorganized active play for at least } 2 \text { hours per day according to a } \\
\text { pilot unpublished study }(\mathrm{n}=175) \text {. No data is available on time spent outdoors. }\end{array}$ \\
\hline Active Transportation & $\mathrm{C}+$ & $\begin{array}{l}59 \% \text { of } 9 \text { - to } 17 \text {-year-olds report using active modes of transportation on the main part of their trip between home and } \\
\text { school }\left(\mathrm{HBSC}^{6} \mathrm{IPEN}^{7}\right) \text {. }\end{array}$ \\
\hline Sedentary Behaviors & D- & $\begin{array}{l}21 \text { and } 12 \% \text { of } 11 \text { - to } 15 \text {-year-olds report no more than } 2 \text { hours of screen-time on an average day (HBSC }{ }^{2} \text { ). HBSC } \\
\text { data indicated an increase in the prevalence of sedentary behaviors in both sexes in the } 2002-2014 \text { period. Moreover, } \\
29 \% \text { of youth report less than } 2 \text { hours of screen-time per day according to the IPEN study (unpublished data). }\end{array}$ \\
\hline Physical Fitness & $\mathrm{C}+$ & $\begin{array}{l}\text { The average percentile achieved in aerobic capacity was } 48 \% \text { in boys and } 59 \% \text { in girls in relation to published } \\
\text { international standards. Czech children and youth achieved better results in motor tests assessing other components } \\
\text { of physical fitness (e.g., standing broad jump, bent-arm hang) compared with the normative values. }{ }^{8}\end{array}$ \\
\hline Family and Peers & $\mathrm{C}+$ & $\begin{array}{l}\text { Overall weighted mean for this indicator equals } 63 \% .59 \% \text { of } 11 \text { - to } 17 \text {-years-old boys and girls report playing sports } \\
\text { and/or going for walks with their parents regularly. Furthermore, } 85 \% \text { of adolescents indicate having friends to } \\
\text { encourage/support them to be physically active (HBSC, }{ }^{9} \text { IPEN - unpublished). }\end{array}$ \\
\hline School & $\mathrm{B}+$ & $\begin{array}{l}100 \% \text { schools offer the mandated amount of physical education (PE) to a majority of their students. } 83 \% \text { of schools } \\
\text { have active school policies and } 89 \% \text { of schools offer PA opportunities (in addition to PE) to a majority of their } \\
\text { students. Students have regular access to facilities and equipment that support PA in } 80 \% \text { of schools. A majority of } \\
\text { students are taught by a PE specialist in } 63 \% \text { elementary schools and } 81 \% \text { secondary schools }\left(\mathrm{CSI}^{10} \text {; } \text { HBSC and }\right. \\
\text { IPEN - unpublished). There is a decreasing trend in the number of PE specialists over the } 2012-2016 \text { period }\left(\mathrm{CSI}^{10}\right) \text {. }\end{array}$ \\
\hline $\begin{array}{l}\text { Community and } \\
\text { Environment }\end{array}$ & $\mathrm{B}$ & $\begin{array}{l}47 \% \text { of boys and } 57 \% \text { of girls have parks available in their community based on objective assessment of the built } \\
\text { environment using a GIS analysis (IPEN - unpublished). } 77 \% \text { of children and youth (55-89\% range) report living in } \\
\text { a safe neighbourhood where they can be physically active (HBSC and IPEN - unpublished). }\end{array}$ \\
\hline Government & $\mathrm{C}+$ & $\begin{array}{l}\text { All benchmarks were substantially covered by public policy documents, strategies and legislation (e.g., Health } 2020 \\
\text { Strategy, Act on the Promotion of Sport, documents by the Czech Olympic Committee). However, it seems that most } \\
\text { of the policy documents are not linked to the budget in all stages of public policy. Thus, the strategic goals and } \\
\text { provisions seem to have a very low impact in terms of implementation. It is also questionable to assess the progress } \\
\text { and evaluate the impact of public policy because these indicators have been rarely used. }\end{array}$ \\
\hline
\end{tabular}

A higher proportion of objectively measured or triangulated data could enhance the quality of information synthesized.

\section{Conclusion}

There is ample evidence that Czech children and youth are insufficiently active, and the prevalence of physical inactivity and excessive screen-time has increased in both sexes during the last two decades. Thus, PA in childhood and adolescence should be promoted intensively and effective intervention and prevention programs are needed.

\section{Acknowledgements}

The authors wish to thank Petra Hiklová, Aleš Jakubec, Aleš Suchomel and Marie Lipusová for their assistance during development of the Report Card.

\section{References}

1. Sigmund E, Sigmundova D, Badura P, Kalman M, Hamrik Z, Pavelka J. Temporal trends in overweight and obesity, physical activity and screen time among czech adolescents from 2002 to 2014: a National Health Behaviour in School-Aged Children Study. Int J
Environ Res Public Health. 2015;12(9):11848-11868. doi:10.3390/ ijerph120911848

2. Sigmundová D, Sigmund E, Bucksch J, Bad'ura P, Kalman M, Hamř́k Z. Trends in screen time behaviours in Czech schoolchildren between 2002 and 2014: HBSC study. Cent Eur J Public Health. 2017;25(88):S15-S20. doi:10.21101/cejph.a4822

3. Ekelund U, Steene-Johannessen J, Brown WJ, et al. Does physical activity attenuate, or even eliminate, the detrimental association of sitting time with mortality? A harmonised meta-analysis of data from more than 1 million men and women. The Lancet. 2016; 388(10051):1302-1310. doi:10.1016/S0140-6736(16)30370-1

4. Maresova K. The costs of physical inactivity in the Czech Republic in 2008. J Phys Act Health. 2014;11(3):489-494. doi:10.1123/jpah. 2012-0165

5. Gába A, Dygrýn J, Mitáš J, Jakubec L, Frömel K. Effect of accelerometer cut-off points on the recommended level of physical activity for obesity prevention in children. PLoS One. 2016;11(10):e0164282. doi:10.1371/journal.pone.0164282

6. Pavelka J, Sigmundova D, Hamrik Z, Kalman M, Sigmund E, Mathisen F. Trends in active commuting to school among Czech Schoolchildren from 2006 to 2014. Cent Eur J Public Health. 2017;25(suppl 1):S21-S25. doi:10.21101/cejph.a5095

7. Vorlíček M, Rubín L, Dygrýn J, Mitáš J. Pomáhá aktivní docházka/ dojížd'ka českým adolescentům plnit zdravotní doporučení pro pohybovou aktivitu? Tělesná kultura. 2018;40(2):112-116. 
8. Rychtecký A, Tilinger P. Životní styl české mládeže: Pohybová aktivita, standardy a normy motorické výkonnosti. Praha, Czech Republic: Karolinum; 2017.

9. Vokacova J, Badura P, Pavelka J, Kalman M, Hanus R. Brief report: Changes in parent-adolescent joint activities between 2002 and 2014 in the Czech Republic, Health Behaviour in School-aged Children
(HBSC) study. J Adolesc. 2016;51:1-5. doi:10.1016/j.adolescence. 2016.05.006

10. Česká školní inspekce. Tematická zpráva - Vzdělávání v tělesné výchově, podpora rozvoje tělesné zdatnosti a pohybových dovedností. Praha, Czech Republic: Česká školní inspekce; 2016. ČŠIG-2038/16-G2. 